\title{
Introduction: Exile and Social Transformation
}

\section{Paul Allatson and Jo McCormack, Institute for International Studies, University of Technology, Sydney}

The death of Edward Said in September 2003 provided a salutary reminder in the new millennium that exile remains a personal and a communal reality for many people. As the obituary notices in the international press informed readers, aside from his extraordinary contributions to contemporary theory, Said was a tireless advocate for the rights of a people that forms the world's largest exile community, with four million refugees outside Palestine, and those in Palestine arguably enduring a form of internal exile. Said, however, lived and worked in New York from 1963 until his death. His experiences of exile, and his conviction that exile still demands critical and creative attention, were thus further modulated by a city renowned for hosting displaced peoples. As he says in the introduction to his essay collection, Reflections on Exile, 'Exiles, émigrés, refugees and expatriates uprooted from their lands must make do in new surroundings, and the creativity as well as sadness that can be seen in what they do is one of the experiences that has still to find its chroniclers' (2001, xiv).

This special issue of Portal appears in the late Said's shadow with one specific, if broad, brief: to discuss exile and its potential to effect social change. ${ }^{1}$ The critical and creative discussions that follow this introduction respond to a particular set of problems. What factors permit and preclude exilic individual and communal transformation? Is there a need to rethink exilic agency in accord with local times, cultures and places, and to refocus attention on exile communal impacts on a host society? And, in a globalized epoch characterized by mass

\footnotetext{
${ }^{1}$ We would like to thank the many participants at the Symposium and Workshop on Exile and Social Change hosted by the Institute for International Studies, University of Technology, Sydney, in July and December 2004 respectively, for their positive and productive responses to the concerns raised in the working paper on which this introduction is based.
}

Portal Journal of Multidisciplinary International Studies Vol. 2, No. 1 January 2005

ISSN: $1449-2490$

http://epress.lib.uts.edu.au/journals/portal/splash/ 
population movements across geopolitical lines, do states and national desires still have key roles to play in the production of exile? There are no straightforward answers to these questions, but all gesture toward the inadequacy of a single overarching definition or description of exile. As Amy Kaminsky suggests, however exile may be lived or dreamed, it is innately unstable, 'a process rather than a singular state' (1999, xvii). Indeed, the process of exile has generated a great deal of debate regarding to whom the term exile applies and when. Furthermore, a number of unresolved issues recur in the extensive literature on the topic: the problematic location of exile and its definitional dependency on a home or homeland; the multivalent struggles to attain and maintain exilic voice, representation, memory, and identity on many fronts (individual, familial, communal, national, transnational); exile's uneasy relation to modernity, the state, and globalization; and exile's conceptual competition with other terms, such as diaspora, exodus, refugee and migrant. Intended as a selective reprise of these issues and the ways the contributors to this issue have responded to them, this introduction identifies some of the claims that have been made of exile as a space or mode of social transformation, as well as the possible limits of such claims.

What, then, is exile? Said's 'Reflections on Exile,' an essay first published in Granta in 1984, provides perhaps his key statement on this question:

Exile is strangely compelling to think about but terrible to experience. It is the unhealable rift forced between a human being and a native place, between the self and its true home: its essential sadness can never be surmounted. And while it is true that literature and history contain heroic, romantic, glorious, even triumphant episodes in an exile's life, these are no more than efforts meant to overcome the crippling sorrow of estrangement. The achievements of exile are permanently undermined by the loss of something left behind forever. $(2001,173)$

In this passage, exile is cast as a disturbed physical and psychic relation to space and home. Kaminsky, speaking of Latin American exiles from the Southern Cone dictatorships of the 1970 and 1980s, goes further with her claim 'that without the emplaced human body, there is nothing to know or represent about exile and its aftermath’ (1999, xi). However, as Said points out, exile has also had a long metaphorical existence as 'a potent, even enriching, motif of modern culture' (2001, 173). Since Nietzsche at least, western literary and philosophical responses to modernity have often used the exile trope to characterize a prevailing sense of unease, estrangement, and 'spiritual' orphanhood (2001, 173). A mood of dislocation 
dominates western cultures, and Said attributes this by no means fatal or unproductive condition to the impact of constant exile flows, so much so that western literature can be said to be a literature of 'extraterritoriality' (2001, 173-74).

The literary realm for Said thus becomes symptomatic of wider forces, one sign that exile has proliferated in an epoch marked by cataclysmic events and far-reaching processes on a global scale: imperialism and its neo-imperialist successors; decolonization and postcolonial unrest; warfare on hitherto unimagined scales; entrenched ideological enmities; competing nationalisms; revolutions, dictatorships, and fundamentalisms; holocausts and ethnic cleansings; mass migration; mass cultural production and a concomitant consumerist habitus; mass starvation and poverty; AIDS and other pandemics; environmental ruination; transnational capitalism, globalization, and their discontents. Exile would seem to be an inevitable consequence of such pressures in what Said calls 'the age of the refugee, the displaced person, mass immigration' (2001, 174). Many other terms could be deployed—and in recent scholarship have- to designate this exilic age: diaspora, transnationalism, statelessness, homelessness, transmigrancy, errance, nomadism, deterritorialization, borderlessness, cosmopolitanism, transmodernity, translated culture, to name a few.

The current epoch — and the proliferation of terms to designate its demographic mobilitiesthus seems to apply pressure on the orthodox understanding of exile. Most commonly, exile is defined as banishment, a geographical dislocation and a physical separation from home enacted by a state's or a regime's legal system, and intended to prevent certain social actors or groups from effecting change at national or regime levels. Accepting this definition, Thomas Pavel argues that as a form of impelled 'human mobility across geographical and political space,' exile must be distinguished from 'voluntary expatriation,' as well as from slavery and immigration (1998, 26). Exile is most commonly imposed on 'those who count,' the 'publicly important' competitors for, and the critics (writers, artists, politicians) of, state power (1998, 27). Hamid Naficy, however, takes a less prescriptive stance in his discussion of external and internal banishment. He argues that internal banishment, or 'deprivation of means of production and communication, exclusion from public life,' could designate the lived experience of many state subjects who may not be targeted by a state's juridical, legal, or 
policing apparatuses $(1996,123)$.

That said, the notion that exile is a synonym for deprivation does not always pertain. In this issue, for example, David Goodman's essay on the Salar people of north-western China-a state in which ethnic nationalities were officially, and often arbitrarily, created in the 1950sconfirms that exile is a particularly complex process in China, where a Han cultural centre constructs all non-Han peoples as having peripheral status. Goodman, however, shows that notwithstanding the centre-periphery logic, the Salar, an Islamic Chinese community numbering some 100,000, have self-consciously constructed a highly productive communal exile identity within the Chinese state. That exilic status is not characterized by a sense of ethnic or communal victimhood. Rather, it has enabled the pragmatic Salar to take advantage of social and economic reforms, both as beneficiaries of such reforms and as adaptive and mobile social actors in the ongoing socio-economic and political transformation of the Chinese economy. If Goodman's paper shows how the Salar took advantage of a 1950s bureaucratic and administrative drive to define all Chinese as having a 'national ethnicity,' Timothy Amos's contribution to this issue also exposes the state's ability to construct exile groups on an ad hoc and arbitrary basis. Focusing on the eta and hnin during the Tokugawa era in Japan, Amos shows that these once 'outcaste' communities were the subject of state legislation in 1871 that led to their new status as 'former outcastes' or 'new citizens,' names that betray the ambivalence of the purported 'return from exile' they purportedly signify.

Goodman and Amos demonstrate that exile need not entail territorial or cross-border displacement. For his part, Naficy's definition of internal exile indicates that a state may discriminate against internal communities and individuals so that they are exiled at home, their potential to disrupt or challenge the state's operations accordingly limited (1996). Thus, internal exile may be manifested as a form of social death—from short term to life—within the penitentiary, the prison-camp, the asylum, the house converted into a prison, or indeed, the antipodean prison colony (internal exile transported). Beyond those sites of official dislocation, supposedly benign institutions such as the familial home, and social conditions such as enforced or prolonged unemployment, may also function as sites of crushing exile. The flip side of legislated banishment at home is exile chosen to evade a state's legal 
apparatuses. Aside from millions upon millions who have fled the rise to power and operations of totalitarian, dictatorial or simply ideologically unpalatable regimes, judicial evasion characterizes the experiences of innumerable outlaws and fugitives from the law (Casanova, Jessie James, Ronald Biggs, and so on), as well as the exiles of state leaders, often dictators, who become the target of state and international legal authorities once their regimes fall. However, freely chosen exile is not the sole preserve of significant political or criminal agents. In Susana Chávez-Silverman’s evocative ‘Zorrilla Grass Crónica,' which appears in the Cultural section of this issue, the author-narrator meditates on her own youthful flight from Reagan-era U.S.A. to apartheid-conflicted South Africa as a highly ambivalent going 'AWOL,' a fraught attempt to construct a 'self-imposed exilio in Pretoria, exiled from exile (from grad school en un flatlining job market? From Reaganomics?).'

It is also possible to argue that an internal banishment of sorts applies to many native peoples. The doctrine of terra nullius applied by the British to Australia, for example, provides an instance of colonization that functioned by literally excising the continent's indigenous inhabitants from the map, a rhetorical and legalistic gesture upheld by physical dispossession, rigid assimilatory pressures, and genocide. The conquest and dispossession of indigenous peoples in their homelands are not normally included in exile debates. But according to Enrique Dussel, such dispossession is a consequence of a dominating modernity that arose in late fifteenth century Europe, and that was in part constituted on the production of exiles. Dussel argues that prior to 1492, most of Europe had been a periphery for the Islamic world. Spain, and Portugal before it, were crucial in inverting this relationship. The capture of Granada in 1492, the final stage of the reconquista of the Iberian Peninsular, ended the Islamic world's eight-century long claims to a portion of western Europe, and established a pattern of contact as conquest that would be exported to the Americas and elsewhere by Spain and its rivals (1993, 67). 1492 was also the year in which Spain expelled its Jewish population, a fate that would apply to the remaining Islamic communities over the next century. However, the formative role of this conquering-and-banishing double act in the development of 'the modern world system' has been overlooked in contemporary understandings of modernity. As Dussel puts it, the mythotrope of modernity affirms Europe 'as the "center” of a World History that it inaugurates,' while denying that 'the "periphery” 
that surrounds this center is consequently part of its self-definition' $(1993,65)$. And that denial enabled the 'eclipse' (exile) of 'whatever was non-European,' including the relegation of the Iberian Peninsular to the periphery of European modernity $(1995,12)$. It is perhaps ironic, then, that the first Spanish targets of the modernity mythotrope still dominate discussions of exile in the $21^{\text {st }}$ century. As Osama bin Laden has asserted on a number of occasions since 2001, Spain (Al’Andalus) looms in some Arab imaginaries as a lost homeland or exiled paradise, the only territory from the epoch of classical Islam not in Islamic hands. For the Spanish Jews, whose descendants are scattered in North Africa, Israel and Turkey, and who speak a Spanish-Hebrew-Arabic hybrid, the 1492 expulsion continues to inform their communal sense as a people of exile.

That particular communal memory adds an additional exilic trajectory to a long history of Jewish communal displacements out of which has arisen a resilient foundational narrative of religious and cultural identity. In turn, Jewish tropes of exodus and redemptive return continue to inform exile debates in Western Europe and the Americas, and to influence other groups' conceptions of their own displacement. Since 1959, for example, many members of the Cuban sector in the U.S.A. have self-consciously embraced a Judaic notion of exilereplete with parallels drawn between Cuban and Jewish ‘chosen people’ status - to designate their mass presence in Florida. A more prolonged historical influence from Jewish religious lore and intellectual production is evident in the discourses of African-American nationalism, pan-Africanism, and negritude. As Gilroy points out, tropes of exodus, and the associated term diaspora (from Deuteronomy 28:25), were appropriated from Jewish discourses by historians of slavery in the 1950s and 1960s. But the connections run deeper, with Zionist rhetoric of exile and anticipated return to the promised land informing the work of many African-American and Caribbean writers in the nineteenth and early twentieth centuries (1993, 208). For the descendants of slaves, particularly in the U.S.A., exodus or diaspora and return provided a powerful consolatory metaphor by which to comprehend and cope with a history of enforced displacement, violence, corporeal commodification, and post-slavery discrimination (Gilroy 1993, 207). A parallel example of this tendency is provided by the many post-colonial conversions of Caliban, the enslaved monster from Shakespeare's The Tempest, into the embodiment of the exile most familiar to slaves and their descendants in the 
Americas. For George Lamming, the Barbados-born writer, Caliban’s paradigmatic exile-a deprivation of language, proper name, and place_-also affords some pleasure. The imperial centre is now confronted by the uncountenanced return of its language, and the presence of the voiced Other, in ways that invert the exilic relations of colonization $(1992,15)$.

In Jewish discourses, however, the terms exile and diaspora are not regarded as synonymous, a semantic distinction that Barkan and Shelton contend derives from an ideological contest within Zionism exacerbated by the founding of the Israeli state and the reluctance of many Jewish people to live there. That reluctance incited some architects of the Jewish state to seek an alternative to exile, with its historical connotations of suffering, violent dispersal, and lack of choice $(1998,4)$. The Greek word diaspora provided a semantic solution for the problem: 'exile connoted suffering, a negative term evoking displacement, refugee status, and above all the myth of an eventual, and possibly soon, return. In contrast, diaspora came to mean a chosen geography and identity’ $(1998,4)$. Within Israeli state discourse, the terms exile and diaspora came to signify mutually exclusive Jewish conditions: 'Exile was largely revered for the cultural stamina of the exiles, their constant loyalty to the historical memory of the communal life, rejection of assimilation, and struggle for authenticity and sacrifice. In contrast, the Jewish diaspora has been envied for its material success and simultaneously denigrated as selfish and failing to contribute to the general good' (1998, 4). Examining this ideological and conceptual contest, Anna Hartnell's contribution to this special issue focuses on the writings of David Grossman, in whose texts the tropes of Zionism and diaspora compete and collaborate. Hartnell deploys Said's arguments on secular and religious modes of cultural identification to argue that if the exile-diaspora dispute in Jewish and Zionist discourses is 'crucial for the elaboration of Israeli identity,' it also suggests that Said's approach to exile potentially enables a conciliation between 'homeless identities' and an essentialist 'identity politics.'

Despite the distinction between diaspora and exile in Jewish debates, exile seems to have lost ground to diaspora in recent cultural criticism. For example, while the brief of Diaspora: A Journal of Transnational Studies is to focus on the 'traditional diasporas'-Jewish, Greek and Armenian-its ground-breaking critical discussions of diaspora's applicability to other 
peoples have greatly assisted in the critical popularization of the term as a sign of new transnational social and discursive transformations. Also adopting the diasporic term, Rey Chow suggests that 'the goal of "writing diaspora” is ... to unlearn that submission to one's ethnicity such as "Chineseness” as the ultimate signified' (1993, 25). She thus calls for a diasporic intellectual resistance to and noncomformity with fantasy images of 'Chineseness,' whether determined by the Chinese state or western discourses of oriental ethnicity. For Gilroy, an historicized account of diaspora helps to explain and learn from the intellectual traffics of the 'black Atlantic,' most notably between black and Jewish intellectual currents concerned with redemption in the face of historical oppression $(1993,211)$. That concern with redemption also animates Dussel's re-reading of exodus. Dussel's liberatory ethics aim to provide an array of subalterns_-'The poor, the oppressed class, the peripheral nation, the female sex object'—with a praxis by which hegemonic processes may be challenged (1998, 243). In this praxis the primary Biblical scenario of exodus is cast as the exilic liberation 'from Egypt, to the promised land, through the wilderness' (1998, 241). This trajectory targets systemic material and discursive oppressions and asks how subalterns might manage 'the passage from the “old” order to the "new," not yet prevailing, order' $(1998,241)$. Exilic liberation thus requires a politicized awareness of multiple oppressions without which there is no basis for active resistance.

Hardt and Negri also make use of the exodus trope in response to imperial postmodernity. Empire is at once a concept of untrammelled global reach, an ahistorical eternity, and a deeply penetrative and hierarchized social realm that controls people, territories, and thus its own constructed world, one that appears, due to its placement outside history, as a vast zone of 'peace' (2000, xiv-xv). In surmising how resistance to this new Empire might be managed, Hardt and Negri see in the 'specter' of migration the ideal subjects for an exodus that will lead to 'the evacuation of the places of power' (2000, 212-13). Migration for Hardt and Negri encompasses economically impelled flight from the poorest parts of the world, as well as 'flows of political refugees and transfers of intellectual labor power' (2000, 213). Nonetheless, Hardt and Negri note that while 'Desertion and exodus are a powerful form of class struggle within and against imperial postmodernity,' such mobilities seem only to lead to 'a new rootless condition of poverty and misery' (2000, 213). Faced by that predicament, 
the authors advocate two types of exodus: an 'anthropological exodus' composed of resisters whose bodies are 'incapable of submitting to command ... of adapting to family life, to factory discipline, to the regulations of a traditional sex life, and so forth' (2000, 215-16); and a 'machinic exodus,' by which 'the subject is transformed into (and finds the cooperation that constitutes it multiplied in) the machine' (2000, 366-67). Ideally, this exodus will engender a contest between claimants to the real and the virtual, the aim being the seizure 'of the processes of machinic metamorphosis,' (2000, 367).

Hardt and Negri's machinic exodus recalls many other postmodernist responses to globalizing pressures, evident in a widespread critical dependence on metaphors of displacement, deterritorialization, desertion, and their synonyms. Yet, as Kaplan points out, like 'most EuroAmerican modernist versions of exilic displacement' that emphasize 'the freedom of disconnection and the pleasures of interstitial subjectivity,' the escape that post-modernist discourses promise also conforms to a colonizing logic: 'The movement of deterritorialization colonizes, appropriates, even raids other spaces' $(1995,89)$. Hardt and Negri regard space as an ever-expanding zone of promise, of resistant potential and neo-identificatory possibility founded on mobility itself. But this faith in movement as an utopic enterprise is nonetheless predicated on an ability to access and profit from the technologies of virtuality that remain beyond the means of most of the planet's inhabitants.

Such critical faith in mobility raises for us the issue of agency, particularly in an epoch when all manner of displacements, freely chosen and impelled, are challenging, and being met with resistance at, national borders. For whom precisely is cross-border displacement a desired end, and with what motives and rewards? Noting the critical popularization of the diaspora concept, Barkan and Shelton explain that its universalization has in part arisen because many of its main proponents are cosmopolitan intellectuals, writers and critics, for whom the term designates the post-national '“nonnormative” intellectual community' to which they belong and identify $(1998,5)$. For this community, Barkan and Shelton propose, the concept of diaspora itself provides a solution to the exclusionary practices of both nationalism and colonialism: 'Diaspora is a culture without a country, ironically the exact antithesis of the internal coherence and integration implied by the notion of national culture. Diaspora is about 
choice. At a political level, the choice is manifested by adopting a voice, which even though ambivalent and fragmented can provide the tools that may serve to dismantle the enduring relations of colonialism' $(1998,5)$. Similar claims of the counter-hegemonic credentials of cosmopolitanism were made by the editors of a special issue of Public Culture on cosmopolitanisms, for whom the term designates a 'minoritarian modernity' practiced and lived by 'the victims of modernity, failed by capitalism's upward mobility, and bereft of those comforts and customs of national belonging' (Breckenridge et al. 2000, 582). And yet, in what amounts to a dehistoricized list of disparate displacements that recalls Hardt and Negri's migrating spectre-'Refugees, peoples of the diaspora, and migrants and exiles represent the spirit of the cosmopolitan community' - the editors insist that cosmopolitanism is not to be equated with a 'cultural pluralism’ located 'within a national frame' (2000, 582).

Nonetheless, the post-national coordinates of cosmopolitanism arguably deflects attention from the fact that this ideal 'cosmopolitan community,' which might include exiles, can only emerge within a frame of globally legible class mobility. Jeffrey Browitt's essay in this issue explores one instance of privileged exile by focusing on the first novel of migration to the U.S.A. written in Spanish, the little-known Lucas Guevara by the Colombian émigré Alirio Díaz Guerra. Díaz Guevera’s novel—evidence of his seamless integration into a Latin American elite community that had access to means of production and publication—provides a vivid account of early twentieth-century New York City in which migrants from many countries have converged, only to be ontologically destabilized by their experiences of an overwhelming ‘American' modernity and pervasive transculturating processes. As Browitt demonstrates, the anxieties and threatening 'melting-pot' challenges laid bare in Díaz Guerra's novel do not elide with the displacement experienced by the text's author.

In her analysis of modernist and post-modernist tropes of travel and displacement, Kaplan is highly critical of the critical popularity of and faith in cosmopolitanism. She argues that the term has replaced 'bourgeoisie' to signify 'the emergent power brokers who know and see nothing but their own self-interest yet legitimate and rationalize their actions by recourse to the rhetoric of humanism' $(1995,126)$. Kaplan also links cosmopolitanist rhetoric to earlier modernist understandings of exile 'as an ideology of artistic production,' one claimed by 
'Euro-American middle-class expatriates’ in the nineteenth and twentieth centuries:

Euro-American modernisms celebrate singularity, solitude, estrangement, alienation, and aestheticized excisions of location in favor of locale - that is, the 'artist in exile' is never 'at home,' always existentially alone, and shocked by the strain of displacement into significant experimentations and insights. Even more importantly, the modernist exile is melancholic and nostalgic about an irreparable loss and separation from the familiar or beloved. $(1995,28)$

As with the cosmopolitan border-crosser under globalization, glossed over in the romanticized retreat into exile chosen by hundreds of modernist artists and writers-in Paris, London, Berlin, New York, the south of France, the south Pacific—are the socio-economic and other privileges (gender, racial, national) that fund and facilitate the line of flight, and permit the reformulation of displacement into a metaphor for artistic work, intellectual endeavour or political critique. And yet, such lines of flight could themselves generate forms of exile. Jennifer Higgie's marvellous novel Son, whose second and concluding part is included in the cultural section of this issue, ${ }^{2}$ provides a fictional account of an exile that may best be described as a psychic breakdown inaugurated by a 'grand tour' of southern Europe and the Middle East. Inspired by the life of Richard Dadd, the renowned Victorian painter and an inmate of Bethlem Hospital (Bedlam), Higgie's novel reveals how the European desire to encounter, experience and represent exotic otherness - another example of the modernity mythotrope in action—was a highly ambivalent and potentially fraught enterprise for agents of the European imperium: such desires could lead to a paradoxical exile from the self.

Said recognized the limits to exilic agency by differentiating between voiced and voiceless exile conditions. While he concedes that the works of exiled writers 'lend dignity' to exiled peoples, he also argues that their texts can only partially account for exile travails: 'to concentrate on exile as a contemporary political punishment, you must therefore map territories of experience beyond those mapped by the literature of exile itself. You must first set aside Joyce and Nabokov and think instead of the uncountable masses for whom UN agencies have been created' (2001, 175). Kaplan, however, argues that Said's counterpointing of the literate, literary exile intellectual or writer with the refugee 'masses,' potentially relegates the refugee outside discourses of representation and 'reduces the refugee to ultimate

\footnotetext{
${ }^{2}$ For the first half of Son, see the Cultural section of Portal vol. 1, no. 2, July 2004.
} 
victim, pinned in lumpen opposition to the recoverable memoirs and fictions of the exiled, bourgeois modernist' $(1995,123)$. Kaplan emphasizes the need for an historicizing attention to refugee experiences in order to 'bring a previously invisible category back from the wilderness of the margins of criticism and literature' (1995, 121), and by implication, back into exile debates as well. Refugees, asylum seekers, and so-called boat people are, Said notes, 'a creation of the twentieth-century state' $(2001,181)$, driven by state and globalcapitalist imperatives to seek any better elsewhere, and often forced to confront the reality that 'homecoming is out of the question' $(1995,179)$. Most observers would agree that since the 1970s the transnational movements of peoples have met increased resistance, and anxiety, in the states toward which these peoples are moving. The rise of 'Fortress Europe' rhetoric and policies, for example, is in part attributable to a widespread belief that western Europe is not the product of immigrant waves over many millennia. The normalization in Europe of this notion of belonging to a place, and of a territorial right to be at home, is paralleled by 'Fortress America' and 'Fortress Australia,' two states founded on migration that have legislated to secure their borders from the perceived threat of unregulated migratory flows.

If states are not disappearing, but reconfiguring themselves to both engender and delimit the movements of peoples, the reconstructive nationalism of many exile groups also responds to such state pressures. As Said notes, 'Nationalism is an assertion of belonging in and to a place, a people, a heritage. It affirms the home created by a community of language, culture and customs; and, by so doing, it fends off exile, fights to prevent its ravages' $(2001,176)$. Such avowed commitments to place are nonetheless haunted by the possibility of state dissolution and reconstitution in new forms. Vadura's essay in this issue deals with the exiled Sudeten German population, and chronicles the challenges posed to a minority sector when the very state borders that render such minority status meaningful have shifted in line with wider European power struggles and realignments. Vadura shows that despite being 'hosted' in Germany at various times in the twentieth century, the uneasy Sudeten German relation to the German host society has often encouraged a hardening of national identifications in response to Czech and broader German state enterprises and nationalist rhetoric. That said, Vadura provides a fascinating account of the attempts in the 1990s by Sudeten Germans and successive Czech administrations to achieve reconciliation and restitution. 
At times, the combined weight of state practices and nationalist desire engenders a type of exile that is righteous, intractable, resolutely nostalgic, suspicious of others, and in denial over the identificatory mutations of community members separated from the originary home/land. Said attributes this atrophic tendency to a communal sense that in exile 'nothing is secure,' that protective lines must be drawn around the exile collective whose memories must then be jealously, passionately guarded $(2001,178)$. For Said, the intransigent case in point is provided by the Israeli-Palestinian conflict:

What could be more intransigent than the conflict between Zionist Jews and Arab Palestinians? Palestinians feel that they have been turned into exiles by the proverbial people of exile, the Jews. But the Palestinians also know that their own sense of national identity has been nourished in the exile milieu ... where the slightest deviation from the accepted group line is an act of the rankest treachery and disloyalty. $(2001,178)$

Another example of exilic intransigence is discussed with great sensitivity by the CubanAmerican-Australian writer Olga Lorenzo in this issue. Lorenzo’s autobiographically modulated essay reflects on her own and other Cuban-American writers' fictional works in order to reveal how mechanisms of shame have dominated the Cuban exile imagination in the U.S.A. and elsewhere. For Lorenzo shame does not simply generate an intense and intransigent nostalgia for the lost Cuban home; it also precludes dissent and prevents individuals, families and communities from reconciling themselves to the past. Lorenzo asserts the need for writers to foreground exilic shame and thus 'force it to shrivel in the glare of, for example, literary acceptance.'

The operations of exilic shame do not simply confirm Kaplan's point that exile ‘triggers strong responses’ $(1995,141)$. They also highlight the inherent paradox of exile communal nationalism forged beyond the originary home/land, in what Said calls 'the perilous territory of not-belonging ... where in the modern era immense aggregates of humanity loiter as refugees and displaced persons’ (2001, 177). For Said, the paradox presented by this extranational liminality lies in how best the exile might come to terms with 'a fundamentally discontinuous sense of being' when the reconstruction of 'an exile's broken history into a new whole.' is at once psychically 'unbearable’ and geopolitically 'impossible’ $(2001,177)$. Exploring the exilic space of liminality, Guilan Siassi's contribution to this issue explores 
Said's particular interest in Erich Auerbach, a Jew exiled in Istanbul during World War Two and perhaps the paradigmatic inhabitant of Said's 'perilous territory of not-belonging.' Siassi applies Said's arguments about liminal exile to shed light on Auerbach's attempt to pursue a secular criticism in exile, a space that permitted a resistant reconstitution of home in response to the traumatic experience of loss. Another contributor to this issue, the Nigerian exiled artist and writer Olu Oguibe, provides a personal account of why art and poetry attain heightened significance for him, and others like him, in coming to terms and making productive sense of exile. As he says, 'The preoccupation with exile recurs in my work and those of others because art provides us with a handle on the fact and memory of dislocation and unbelonging; a safe space to dream and contemplate, even mourn.'

The extranational liminality of exile means that the terms home and homeland acquire enormous symbolic and emotive significance for exiled communities and individuals. But there is a perhaps obvious, but necessary, point to make about home and homeland. Such terms, without which exile is rarely thought or lived, may introduce other axes of dispute into discussions about exile. For example, Kaminsky draws attention to a 'semantic oddity' in Spanish, a language with two words for house, casa and hogar, but no word 'that denotes both "dwelling place" and the affective meaning connected to it that "home" does in English and heim and hem do in other Germanic languages' (1999, 3). Similarly, the Spanish patria, which may also signify a national home of sorts, as well as fatherland, cannot be easily transposed into English. Moreover, the affective uses of such terms in common parlance indicate that pueblo (hometown and people) is preferred to patria when people name their place of origin. For Kaminsky, this amounts to a domestic identification of place with its inhabitants, as opposed to the more formal public or state registers in which patria would appear (1999, 3). The key to this linguistic 'contraction' and 'expansion' is the domestic realm, the sign that in Spanish at least, talk of home/land is determined by a gendered ideology that naturalizes the house/hearth as feminine, as opposed to the wider masculine space of the país (country) or patria (1999, 3-4). The implications for women, at least, are clear: how can we speak (in Spanish, in any language) of women's exile from a place (the fatherland) that traditionally has been foreclosed to them? 
The trouble posed by the notion of home/land is also exposed by the experiences of many freely-chosen exiles, for example, the expatriates associated with imperial and colonizing projects, the 'Colonial officials, missionaries, technical experts, mercenaries, and military advisers,' described by Said as being 'on loan,' that is, living and dwelling away from home secure in the knowledge that return remains an option, even when that return is not realized (2001, 181). For many such expatriates, their exile may only become evident on the return to a place that no longer signifies or functions as home. The complex demographic legacies of the French-Algerian conflict provide a case in point, although in this case, 'expatriate' status is more often imposed rather than freely chosen. Significant numbers of two groups to emerge from the Algerian War (1954-1962), the 'harkis' (Algerian forces recruited into the French army but largely left to their fate after Algerian independence) and 'pieds noirs' ('repatriated' European settlers), have managed the 'return' to France. There they have either constructed nostalgic memories of the Algerian 'home' or occluded and repressed such memories, and have often yet to obtain a 'home' in France. This disturbed national scenario of exile is further complicated by the post-independence Algerian community in France, the largest immigrant group in that country, which has also maintained a myth of returning for decades. That return rarely eventuated, however, given the change from the single male rotation system of the 1950s and 1960s to an immigration policy in the 1960s and 1970s intended to ease domestic unemployment by limiting the opportunities for extra-European work immigration. In reality, this policy encouraged Algerian workers to stay in France, and few immigrants took up the government's offer of a financial incentive to return home. The children of these immigrants are torn between homeliness in a France that does not fully accept them, and an Algerian 'homeland' that is alien to them, as is evident in a host of literary and artistic attempts to construct memories of Algeria despite displacement (Hargreaves 1989).

Such projects of memorialization typify the concerns of many exile writers and artists who see in memory a vector for individual, communal and national validation. The central function of memory in exile processes is again related to the troubled exilic relation to home/land. As Said puts it, 'Exiles feel ... an urgent need to reconstitute their broken lives' (2001, 177) and 'Much of the exile's life is taken up with compensating for disorientating loss by creating a new world to rule' $(2001,181)$. That attempt at compensation, which arises with 
the exilic crossing of national, legal, linguistic and cultural borders, thus characterizes the imaginative and recuperative work of remembering. But for Said, the difficulties posed by exilic memory are qualified by the fact that memory is at imaginative work in a contrapuntal sense, located in the past and in the host society's present:

For an exile, habits of life, expression, or activity in the new environment inevitably occur against the memory of these things in another environment. Thus both the new and the old environments are vivid, actual, occurring together contrapuntally. There is a unique pleasure in this sort of apprehension, especially if the exile is conscious of other contrapuntal juxtapositions that diminish orthodox judgment and elevate appreciative sympathy. There is also a particular sense of achievement in acting as if one were at home wherever one happens to be. $(2001,186)$

As this passage confirms, exile can signal a place where past and present 'homes' co-exist pleasurably. This is a point taken up by Obododimma Oha in this issue, who proposes that Europe has emerged as a productive venue for the exilic/migrant African text in the postindependence era. Analysing the images of home/land in the exiled Nigerian poet Uche Nduka's The Bremen Poems, a work Oha describes as a textual politics of re/identification, Oha shows how Nduka attempts to map his productive homeliness despite exile in the city of Bremen, the 'City of Refuge,' as well as in the Europe that spreads out from that city.

For Marianne Hirsch, however, generational factors complicate Said's notion of contrapuntal exilic memory. Speaking specifically of the children of Holocaust survivors, Hirsch argues that these members of the generations born away from the home/land have an 'imaginative investment' in 'postmemory.' Unlike the first generation of exiles, newer generations have no direct experiences of a place of departure, and hence no capacity to imaginatively rely on memories of that place $(1998,420)$. As a consequence, 'Postmemory characterizes the experience of those who grow up dominated by narratives that preceded their birth, whose own belated stories are displaced by the stories of the previous generation, shaped by traumatic events that can be neither fully understood nor re-created' $(1998,420)$. This is precisely the narrative terrain that concerns Australian-Hungarian artist, Sue Hajdú. Her beautifully meditative contribution to this issue represents, on the one hand, an account of her relationship to her Hungarian-born father, and on the other, her response as a photographer to the disturbing photographs her father took in the last days of the 1956 uprising before leaving Hungary. As Hajdú says, the artwork she discusses and presents in her piece 'emerges from 
my position as a member of the Hungarian diaspora, whereby my very existence and identity as a member of a diaspora owes itself to a historical event that I am unable to lay claim to.'

The reconstitution of exilic memory among second, third or later generations complicates Pavel's assertion that unlike immigrants, 'exiles never break the psychological link with their point of origin. Among the features of exile must thus be included the coercive nature of the displacement, its religious or political motivation, and the exiled's faith in the possibility of homecoming' $(1998,26)$. Indeed, as many critics have noted, the longer the period of exile the more it may resemble a 'long-distance nationalism' enabled by 'transnational social fields' of experience and habitation. These are Schiller and Fouron's terms for the understanding by which many transmigrants regard, and remain attached to, their 'home' country from a base in another state (2001, 3). For transmigrants, like many exiles, 'transnational social fields' often appear to license a 'claim to membership in a political community that stretches beyond the territorial borders of a homeland' (2001, 4). This notion of belonging despite distance, and despite identificatory investments in a new place, may generate new exile imaginaries and processes. Kaminsky speaks of the Latin American exiles who returned to Argentina, Uruguay and Chile after the end of dictatorship, and of how many of those exiles have constructed a 'routine of travel' between the Latin American 'home' and the society that hosted them as exiles $(1999,2)$. Exile in this instance combines a complex transnational reality with the metaphorical potential encoded in the term itself.

The critical and creative pieces that comprise this special issue take up and shed new light on the debates loosely sketched in this introduction. They demonstrate, in agreement with Said, that more can and must be said about exile in the contemporary world. In line with the special issue’s brief to explore the nexus between exile and social transformation, these essays, autobiographical meditations, and creative responses, are also in accord with Kaplan's call for a questioning of exile and the claims made of it. As Kaplan says, acknowledging the realities of exilic pain and loss, and the metaphorical resonances of exile for most residents of modernity, ought not to preclude the critical questioning of exile’s discursive, representational, and ideological parameters: 'If anything, investigating the critical uses of exile may reinvigorate activism and resistance to state-sponsored terror by fostering a 
politically responsible cultural criticism’ (1996, 141-42).

\section{Reference List}

Bammer, A., ed. 1994, Displacements: Cultural Identities in Question. Bloomington: Indiana University Press. Barkan, E., and M. Shelton, eds. 1998, Borders, Exiles, Diasporas. Stanford: Stanford University Press.

Breckenridge, C.A., S. Pollock, H. K. Bhabha, and D. Chakrabarty, eds. 2000, Cosmopolitanism special issue. Public Culture 12.3 (Fall).

Chow, R. 1993, Writing Diaspora: Tactics of Intervention in Contemporary Cultural Studies. Bloomington: Indiana University Press.

Dussel, E. 1993, 'Eurocentrism and Modernity (Introduction to the Frankfurt Lectures).' In The Postmodernism Debate in Latin America. Eds. J. Beverley and J. Oviedo. Special Issue of Boundary 220.3 (Fall): 65-76.

Dussel, E. 1995, The Invention of the Americas: Eclipse of 'the Other' and the Myth of Modernity. Trans. M. D. Barber. New York: Continuum.

Dussel, E. 1998, Ethics and Community. Trans. R. R. Barr. Theology and Liberation Series. New York: Orbis. Gilroy, P. 1993, The Black Atlantic: Modernity and Double Consciousness. London and New York: Verso.

Hardt, M., and A. Negri. 2000, Empire. Cambridge, MA, and London: Harvard University Press.

Hargreaves, A. G. 1989, 'Resistance and Identity in Beur Narratives.' Modern Fiction Studies 35.1 (Spring): 87102.

Hirsch, M. 1998, 'Past Lives: Postmemories in Exile.' In Exile and Creativity: Signposts, Travelers, Outsiders, Backward Glances. Ed. S. R. Suleiman. Durham, NC, \& London: Duke University Press. 418-46.

Kaminsky, A. 1999, After Exile: Writing the Latin American Diaspora. Minneapolis: University of Minnesota Press.

Kaplan, C. 1995, Questions of Travel: Postmodern Discourses of Displacement. Durham: Duke University Press.

Lamming, George. 1992 [1960], The Pleasures of Exile. Michigan: University of Michigan Press.

Naficy, H. 1996, 'Phobic Spaces and Liminal Panics: Independent Transnational Film Genre.' In Global/Local: Cultural Production and the Transnational Imaginary. Eds R. Wilson and W. Dissanayake. Durham, NC: Duke University Press. 119-44.

Pavel, T. 1998, 'Exile as Romance and as Tragedy.' In Exile and Creativity: Signposts, Travelers, Outsiders, Backward Glances. Ed. S. R. Suleiman. Durham, NC, \& London: Duke University Press. 25-36.

Said, E. 2001, Reflections on Exile and Other Essays. Cambridge, MA: Harvard University Press.

Schiller, N. G., and G. E. Fouron. 2001, Georges Woke Up Laughing: Long Distance Nationalism and the Search for Home. Durham, NC, \& London: Duke University Press. 